\title{
$\mathrm{KC}-100$ 전기체 정적 구조시험
}

\author{
심재열*, 정근완, 이한용, 이상근, 황귀철, 안석민
}

\section{KC-100 Full-scale Airframe Static Test}

\author{
Jae-yeul Shim*, Keunwan Jung, Hanyong Lee, Sang keun Lee, \\ Gui-Chul Hwang and Seokmin Ahn \\ Aeronautics Technology Division, Korea Aerospace Research Institute
}

\begin{abstract}
A full-scale static test for a composite structure small aircraft (KC-100) was conducted in the KARI. The test includes 15 full-scale test and 7 local test conditions. Test requirements with test schedule, test article with dummy structures, test load generation, test system, and equipment are introduced for the test. Test load data of the 1st test condition(U1) was analyzed to evaluate an accuracy of load control for the test. The analysis results show that load data obtained during test were within tolerance of Static Null Pacing Error(SNPE) and the error value of load control was $8.6 \mathrm{~N}$. The error of load controls for the full-scale static test using dozens of actuators was calculated by a method suggested by authors. Test data for all other test conditions is also shown in this paper. Finally, reactions measured from restraint system of the U1 test condition show that the reaction changes as load increment. The factors which may change the change of reactions for a full-scale static test are introduced in this study.
\end{abstract}

\section{초 록}

항우연에서는 복합재 소형항공기(KC-100)에 대하여 15 가지 전기체 시험조건과 7 개의 국 부적 시험조건들에 대한 전기체 정적구조시험을 수행하였다. 시험요구도, 시험일정, 시험 체 및 더미구조, 시험하중산출, 시험장치, 시험장비 등을 소개하였다. 수십개의 제어채널을 사용하는 전기체 구조시험의 하중제어의 정확도를 살펴보기 위하여 U1의 시험데이터를 분석하였다. 분석결과 각 채널별 데이터 획득된 하중값은 허용오차인 SNPE(Static null pacing error)값 이내에서 잘 유지하고 있음을 보였고 본 논문의 저자가 제안한 시험의 하 중제어오차 크기 정의방법을 적용한 결과 U1 시험의 하중제어 오차값이 $8.6 \mathrm{~N}$ 이었고 나 머지 전기체 시험조건들에 대한 시험데이터를 분석한 결과도 보였다. 마지막으로 U1시험 에서 자세제어장치에서 측정된 반력들이 시험하중 증가와 함께 변하는 것을 보였고 전기 체 구조시험에서 반력변화 발생의 요인들에 대하여 기술하였다.

Key Words : KC-100 Aircraft(KC-100 항공기), Full-scale Static Test(전기체 정적시험), Test $\operatorname{Load}($ 시험하중), $\mathrm{CMF}$ (하중제어오차), $\mathrm{RMSD}$ (평균 제곱근 편차), Reaction(반력), SNPE(Static null pacing error)

† Received: September 2, 2013 Accepted: December 27, 2013

* Corresponding author, E-mail : jyshim@kari.re.kr http:/ /journal.ksas.or.kr/ pISSN 1225-1348 / eISSN 2287-6871 


\section{I. 서 론}

국내 최초의 국제적 인증기준에 부합하는 민 수 완제기인 4 인승 소형항공기(나라온, KC-100) 개발에 한국항공우주연구원은 항공기 설계/해석 /시험분야의 업무에 참여하였다. 특히, 한국항공 우주연구원은 전기체 정적시험과 피로시험을 준 비 및 수행하였고 이를 위하여 시험하중 산출, 시험장치 설계, 장비준비, 시험수행 등을 담당하 였다. 전기체 구조시험은 항공기 인증의 주요 일 정에 맞추어 진행되었고 비용의 절감을 위하여 정적시험 종료 후 피로시험을 수행하여 동일 시 험 장치들을 최대한 공동으로 사용하였다.

전기체 구조시험을 수행하기 위해서 시험후레 임, 하중부가장치, 중량보상장치, 자세구속장치, 잭킹장치 등의 주요장치가 필요하고 또한 통합된 시험장비들(제어장비, 데이터획득장비, 유압장비 등)이 필요하다[1 3]. 본 논문에서는 $\mathrm{KC}-100$ 전 기체 정적시험을 수행하기 위한 시험의 요구도, 시험체 및 더미구조, 시험하중 산출, 시험장치, 시험장비 등에 대하여 소개하였다. 아울러 시험 의 정확도를 향상시키기 위하여 개발된 시험장치 의 설치절차도 소개하였고 이 절차에 따른 시험 설치의 결과들을 소개하였다. 마지막으로 수십개 이상의 하중제어채널을 요구하는 전기체 정적시 험에서 시험의 정확도에 영향을 주는 하중제어의 오차를 시험데이터를 이용하여 평가하였고 시험 동안 발생하는 반력의 크기를 보였다.

\section{II. 본 론}

\section{1 시험 요구도 소개}

KC-100 전기체 정적시험에서 제시된 전체 22 가지 시험조건이 있으며, 일정은 초도비행 전에 요구되는 5 가지 시험조건 수행이 완료되어야 하 고, 다른 시험조건들도 주요 인증일자에 부합하 도록 수행되어야 한다. 그리고 특히, 시험의 품질 유지를 위한 합치성 만족 절차를 개발하도록 요 구하였다.

본 절에서는 본시험에 대한 시험일정, 시험조 건, 측정센서 정보, 주요 시험설치 절차에 대하여 설명하였다.

\subsection{1 시험일정}

항공기 개발 주요일정 중 전기체 정적시험과 관련이 깊은 것은 개발항공기의 초도비행 $(\mathrm{FF}$ : first flight)이다. 항공기 개발 일정 계획에서 초

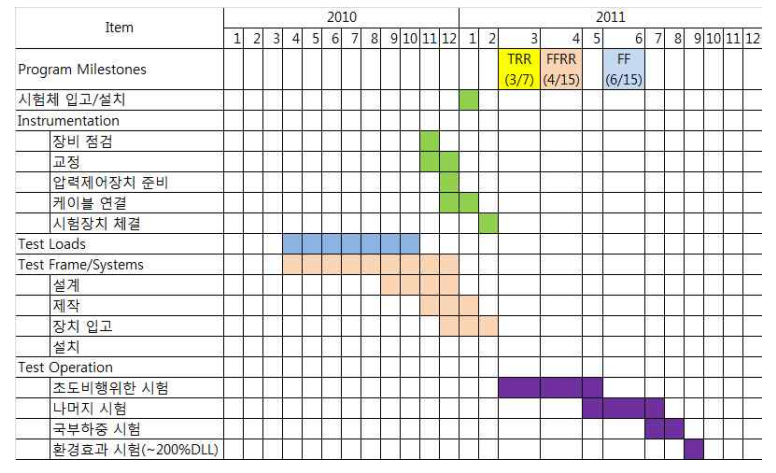

Fig. 1. Plan for KC-100 Static Test

도비행 검토회의(FFRR: first flight readiness review) 이전에 초도비행에 필수적인 시험들에 대한 시험완료를 요구하게 된다. 시험진행 당시 FFRR과 FF는 Fig. 1에서와 같이 4월15일과 6월 15 일이었다. 한편 정적시험보고서는 작성완료일 은 형식검사승인서(TIA, Type Inspection Authority) 제출 이전에 제시되어야 하므로 전체 시험의 종료일자는 2012. 3. 30 이전으로 결정되 었다.

\subsection{2 시험조건 및 시험순서}

본 시험에서는 초도비행을 위한 5 가지 시험조 건(조종면, 플랩 하중조건과 연료탱크 내압시험) 및 6가지의 국부하중시험 조건(Pilot seat, Passenger seat, Engine, Nose landing gear, Turn Over 등)을 포함하여 총 22가지 시험조건 이 고려되어 수행되었다[3]. 본 시험에서는 각 시 험별로 극한하중까지 시험을 진행하였고 시험진 행의 순서는 초도비행을 위한 전기체 시험, 나머 지 전기체 시험, 국부하중 시험, 최종적으로 환경 요소반영 극한하중시험 순으로 진행되었다.

\section{1 .3 측정센서 및 채널}

본 시험에서는 하중, 압력, 스트레인, 변위값을 측정하기 위해서 시험체 거동특성을 위한 측정 센서들(스트레인 게이지/변위측정장치)을 주날개, 동체, 꼬리날개, 더미에 각각 $142 / 14,165 / 5$, $76 / 12,5 / 0$ 개를 사용하였으며 채널수로는 각각 $244,234,104,5$ 로 총 587 채널이 사용되었다. 한 편 각 시험조건별로 하중부가장치는 정확한 하중 작용을 부가하기 위하여 하중부가장치를 변경하 여 설치하였다. 본 시험에서 사용한 하중부가를 위한 유압작동기의 채널수는 일정하지 않으며, 최대 30여개의 채널로 시험이 진행되었다.

\subsection{4 주요 시험설치 절차 개발}

본 시험에서는 시험의 정확도를 높이기 위하 여 「시험장 기준표시」절차, 시험체 설치절차, 
하중부가장치 설치절차 등을 개발하였다. 시험장 기준표시 절차는 참고문헌 [4]에 자세히 기술하 였고 이 결과로서 “개선된 후레임"의 설계를 완 성한 후 확보한 기준과 참고점들을 활용하여 시 험체와 시험장치의 설치효율 및 시험의 정확도를 향상시키도록 하였다.

시험체 설치 절차에서는 시험체 조립공정에서 표시한 시험체 스킨의 스테이션 선들과 시험장 기준선과를 비교하면서 시험체를 정확한 위치에 설치하도록 하였다. 스트랩(또는 패드) - 휘플트 리 - 유압작동기로 구성되어 시험체에 하중을 부 가하는 하중부가장치의 스트랩과 패드는 시험체 스킨에 부착시 기준이 되는 선들을 마일러를 통 하여 표시한 후 부착 또는 설치하였고 유압작동 기는 시험장 기준표시와 후레임에 표시된 참고점 들을 이용하여 보다 정확하게 설치하였다.

\section{2 시험체 및 더미구조}

전기체 정적구조 시험체는 항공기의 구조와 일치해야 한다. 단, 구조를 구성하는 부품 중 시 험의 대상이 아닌 것은 제외될 수 있으며, 제외 하고자 하는 부품 중 시험하중의 전달이 시험의 목적상 필요한 것은 적어도 더미구조를 사용하여 시험하중의 전달이 왜곡이 되지 않도록 하여야 한다. KC-100 전기체 정적시험에서 사용한 더미 구조물은 모두 8 가지이고 주요 더미구조물로는 주/보조 착륙장치 조립체, EMS(Engine mounting system) 조립체, 플랩 작동기, 조종면 제어 로드 등이 있다. 더미착륙장치가 조립된 시 험체는 Fig. 2에 제시하였다.

\section{3 시험 하중 산출}

본시험의 시험하중 산출은 항공기설계자(KAI) 가 제공한 설계하중(VMT; Shear force, Bending moment, Torsion)을 기준으로 시험조건별로 중 요영역과 기타영역을 정의하여 그들이 영역에 대 해 일치점에서 각각 $2 \%$ 와 $10 \%$ 이내의 허용오차 율을 적용하였다. 시험하중 산출 방법은 전단력 과 모멘트를 사용하여 계산되는 모멘트 평형식을 기본으로 하는 참고문헌 $[5,6]$ 과 같다. 본 연구에 서의 시험하중 산출은 참고문헌[6]에서 분류한 모멘트 평형식이 사용되지 않는 1 번(구간별 전단 하중 일치 방법)과 2번(구간별 모멘트 일치 방법) 을 제외한 3 번(구간별 대표하중 선정 방법(I))과 4 번(구간별 대표하중 선정 방법(ㅍ)) 방법을 사용 하여 수행하였다.

본 시험의 설계하중에서는 자세구속장치에 하 중이 작용하지않으며, 이를 만족하기 위하여 시

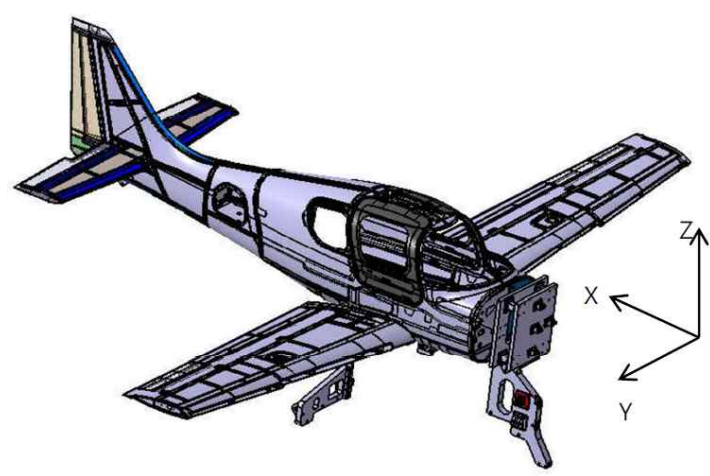

Fig. 2. Test Article with Dummy Structures

험하중 산출에서도 시험하중자체로 평형상태를 잘 유지하도록 하였고 각 구성품별로 아래와 같 이 하중을 산출하였다.

조종면과 플랩에서 하중분포는 무시하고 힌지 모멘트 값만을 만족하도록 요구하였기 때문에 모 멘트 평형식을 사용하지 않고 힌지 모멘트만 일 치시켰다. 조종면과 플랩은 주익과 미익에 위치 하므로 주익 및 미익의 설계 $\mathrm{VMT}$ 에서 조종면과 플랩이 차지하는 시험 $\mathrm{VMT}$ 를 제외한 계산을 수 행하였다. 주익의 경우 넓은 중요 영역을 가지고 있으므로 전체적인 모멘트 오차가 작게 발생하는 장점을 가진 4 번의 방법을 사용하였다. 미익은 사용할 수 있는 시험하중 작용점의 개수가 작은 관계(3개소)로 4 번의 방법은 오차율이 크게 나타 나므로 3 번의 방법으로 시험하중 산출을 수행하 였다. 마지막으로 동체의 경우 무게중심(Center of Gravity, 이하CG점)의 하중이 일치하지 않을 경우 위에서 언급한 바와 같이 자세구속지점에서 반력이 발생되기 때문에 CG점에서 일치시킬 수 있는 3 번의 방법을 사용하였다.

주익에 사용된 방법의 특성상 CG점에서 오차 가 발행하게 되며, 이 오차를 상쇄시키도록 동체 CG 부분에 적용하여 전기체 평형상태를 유지시 켰다. 이상에서 설명한 구성품별 하중산출을 하 였고 조종면 및 플랩, 주익, 미익, 동체의 순서로 계산하였다.

Figure 3에서 Fig. 5는 U3(1511조건, Elevator $\mathrm{Max})$ 의 동체에 작용하는 $\mathrm{VMT}$ 이고 이 시험조건 이 수평꼬리날개 조건인 관계로 수평꼬리날개가 직접 연결되어 있는 후방동체에 오차상쇄 하중을 적용하는 것은 위험하다고 판단되어 주익의 VMT오차 상쇄를 하중을 적용하는 전방동체에 추가적으로 적용하였다. 모멘트와 비틀림 그래프 에서 표시된 부분이 주익 오차로 인해 추가된 부 분이다. 위와 같이 오차 상쇄를 동체로 적용하는 방법으로 시험하중을 산출하였을 때, 전기체 시 


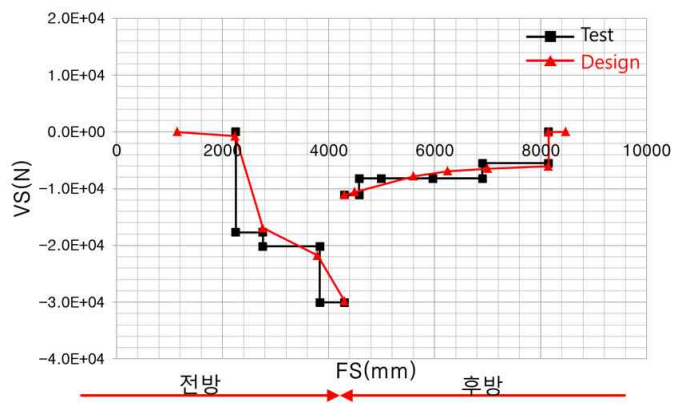

Fig. 3. Shear Graph of Fuselage (1511)

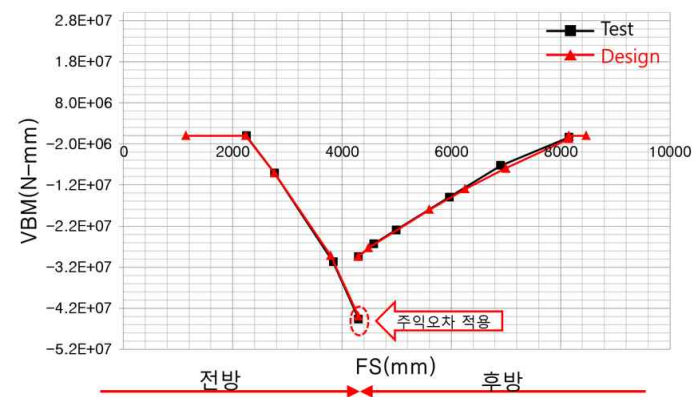

Fig. 4. Moment Graph of Fuselage (1511)

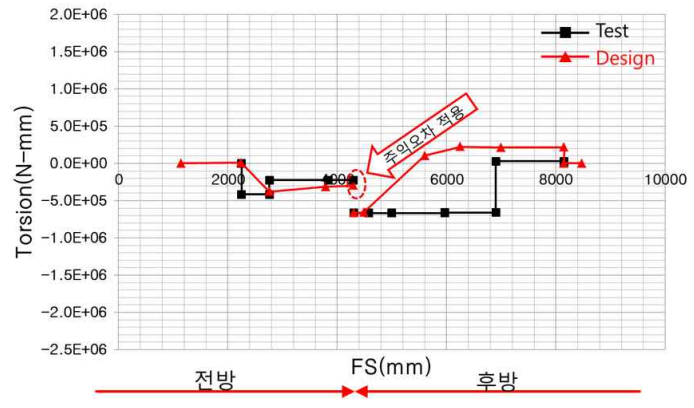

Fig. 5. Torsion Graph of Fuselage (1511)

Table 1. Reaction of Test Conditions

\begin{tabular}{|c|c|c|c|c|c|c|c|}
\hline No & $\begin{array}{c}\text { Load } \\
\text { Case }\end{array}$ & $\begin{array}{c}\text { NLG- } \\
\mathbf{X}\end{array}$ & $\begin{array}{c}\text { NLG- } \\
Y\end{array}$ & $\begin{array}{c}\text { NLG- } \\
Z\end{array}$ & $\begin{array}{c}\text { RML } \\
\text { G-Y }\end{array}$ & $\begin{array}{c}\text { RML } \\
\text { G-Z }\end{array}$ & $\begin{array}{c}\text { LMLG } \\
-Z\end{array}$ \\
\hline 1 & 2510 & 0.0 & 0.1 & -0.2 & 0.9 & -0.4 & 0.6 \\
\hline 2 & 2532 & 1.0 & -0.4 & 0.7 & -0.6 & -0.1 & -0.6 \\
\hline 3 & 1511 & 0.0 & 0.1 & 0.3 & -0.1 & -0.2 & 0.0 \\
\hline 4 & 1510 & 1.0 & 0.0 & 1.1 & -1.0 & 0.3 & -1.4 \\
\hline 5 & 1535 & 0.0 & 0.1 & 0.1 & -0.1 & -0.2 & 0.0 \\
\hline 7 & 1548 & 0.0 & 0.1 & 0.1 & -0.1 & 0.6 & 0.3 \\
\hline 14 & 1509 & 0.0 & -0.1 & -0.2 & 0.1 & 0.5 & 0.7 \\
\hline 15 & 1550 & 0.0 & 0.0 & -0.1 & 0.0 & 0.0 & 0.0 \\
\hline 22 & $1509 A$ & 0.0 & -0.1 & -0.2 & 0.1 & 0.5 & 0.7 \\
\hline
\end{tabular}

(단위 : N)

험에서 시험체 자세구속장치가 부착된 더미착륙 장치에서의 계산된 반력은 모든 시험조건에 대하 여 Table 1 과 같이 $0 \mathrm{~N}$ 에 근접하였고 반력들은 무시할 만한 수준으로 나타났다. Table 1은
$100 \% \mathrm{DLL}$ 에 대한 값이다.

\section{4 시험 장비}

전기체 정적시험 장비는 미국 MTS사의 항공기 구조시험 전용인 Aero-90 시스템이 사용되었고, Fig. 6은 통합 시험장비의 구성도이다. Fig. 6과 같 이 소형항공기 전기체 구조시험에서는 주제어장치, 서보제어장치, 데이터획득장치, 유압시스템, 여압시 스템, 컴퓨터시스템 등이 상호 유기적으로 구성되 고 작동이 된다.

주제어장치는 시험장비 제어를 총괄하고 서보제 어장치는 시험체에 하중을 부가할 유압작동기를 제 어하며, 이는 유압작동기에 부착되는 로드셀과 서 보밸브를 통해 이루어 진다. 본시험에 사용되는 로 드셀은 이중 신호가 출력되는 센서를 사용하였다. 서보밸브의 역할은 목표하중에 해당되는 명령신호 (Command)와 로드셀에서 출력되어 감지되는 피드 백(Feedback)을 실시간으로 연산하여 오차에 해당 하는 신호(CMF, Command Minus Feedback)를 입 력받아 유압작동기의 유량을 제어하여 시험체에 목 표하중을 작용한다. 시험장비의 시스템 설정값에 의해 시험체를 보호하여 안전장치로서의 역할을 하 며, 허용오차와 허용한계치 등을 정의하여 값을 설 정한다. 하중제어는 시험의 안전성과 정확성을 만 족하기 위해 오차(Error)와 한계치(Limit) 값을 결정 하였다. 본 시험에서 적용한 오차와 한계치는 Table 2 와 같으며, 시험하중크기와 로드셀의 최대용량을 기준으로 산출되었다. 아울러 장비의 오작동으로 인해 기체에 과하중이 작용되는 것을 방지하기 위 한 기계적 안전 장치가 사용되며, 대표적으로 과하 중방지장치(Overload Protection System)가 있고 이 들에 대한 자세한 내용은 참고문헌[7]에서 확인할 수 있다. 이 장치에는 하중제한밸브와 미터링 밸브 가 있고 하중제한 밸브는 시험전 조절장치를 통하 여 유압작동기별 최대하중의 $110 \%$ 120\% 범위에서 하중작용이 되도록 밸브를 조절하였다. 미터링밸브 는 시험이 비상중단(shurdown)시 시험체에 내재된 변형율 에너지가 방출되는 과정에서 시험체에 연결 된 인접한 여러개의 유압작동기들에서 하중 제거율 이 유사하게 유지되도록 하는 장치로 시험 전 $40 \% \mathrm{DLL}$ 상태에서 여러번의 인위적인 비상중단을 작용하여 반응하는 유압작동기들의 하중값들로부터 밸브들을 조절하였다.

본 시험에 사용한 로드셀의 선정 기준은 사용 유압작동기의 용량대비 $20 \%$ 보다는 크도록 하고 최 대시험하중이 로드셀 용량의 $20 \%$ 보다는 크도록 하 였다. 유압작동기의 선정은 최대시험하중은 유압작 동기 용량의 $80 \%$ 이상이 되지 않도록 하였다. 


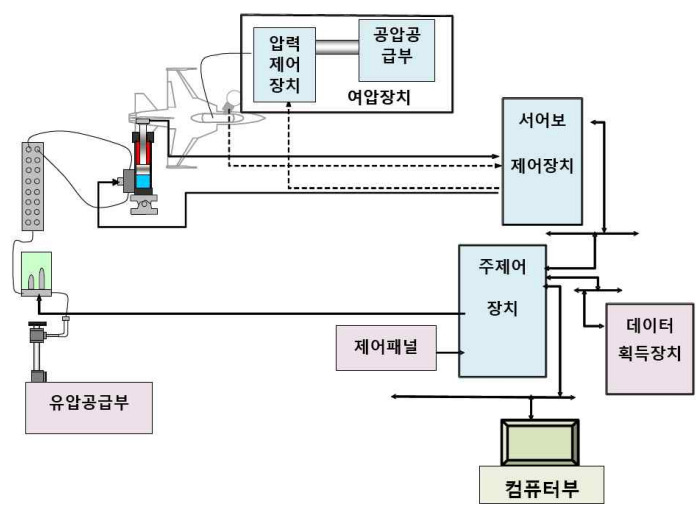

Fig. 6. Integrated Testing System

Table 2. Error and Limit for Load Control

\begin{tabular}{|c|c|c|c|c|}
\hline \multicolumn{3}{|c|}{ Type } & Set Value & Action \\
\hline \multirow{2}{*}{ Error Bands } & \multicolumn{2}{|c|}{ Inner } & $\begin{array}{c} \pm 5 \% \\
\text { (or min. } 0.5 \mathrm{KN} \text { over) }\end{array}$ & Hold \\
\hline & \multicolumn{2}{|c|}{ Outer } & $\begin{array}{c} \pm 8 \% \\
\text { (or min. } 0.75 \mathrm{KN} \text { over) }\end{array}$ & Shutdown \\
\hline \multirow{4}{*}{$\begin{array}{l}\text { Software } \\
\text { Limits }\end{array}$} & \multirow[b]{2}{*}{ Inner } & Upper & $\begin{array}{c} \pm 5 \% \\
\text { (or min. } 0.5 \mathrm{KN} \text { over) }\end{array}$ & $\begin{array}{l}\text { Alarm or } \\
\text { Hold }\end{array}$ \\
\hline & & Lower & $\begin{array}{c} \pm 5 \% \\
\text { (or min. } 0.5 \mathrm{KN} \text { over) }\end{array}$ & $\begin{array}{c}\text { Alarm or } \\
\text { Hold }\end{array}$ \\
\hline & \multirow[b]{2}{*}{ Outer } & Upper & $\begin{array}{c} \pm 8 \% \\
\text { (or } \min .0 .75 \mathrm{KN} \text { over) }\end{array}$ & Hold or Stop \\
\hline & & Lower & $\begin{array}{c} \pm 8 \% \\
\text { (or } \mathrm{min} .0 .75 \mathrm{KN} \text { over) }\end{array}$ & Hold or Stop \\
\hline \multirow{2}{*}{$\begin{array}{l}\text { Conditioner } \\
\text { Limits }\end{array}$} & \multicolumn{2}{|c|}{ Upper } & $\begin{array}{c} \pm 10 \% \\
\text { (or min. } 1.0 \mathrm{KN} \text { over) }\end{array}$ & Shutdown \\
\hline & \multicolumn{2}{|c|}{ Lower } & $\begin{array}{c} \pm 10 \% \\
\text { (or min. } 1.0 \mathrm{KN} \text { over) }\end{array}$ & Shutdown \\
\hline
\end{tabular}

\section{5 시험 장치}

전기체 정적시험에 필요한 주요장치들로는 시 험 후레임, 시험체 자세구속장치, 하중부가장치, 중량보상장치, 잭킹장치 등이 있다[3]. 본 절에서 는 본 시험에 사용된 이들 주요장치들에 대하여 살펴본다.

시험 후레임은 시험체에 하중을 부가하기 위해 사용되는 유압작동기를 지지하는 기본 장치로 Fig. 7[3]과 같고 3 차원 측정을 통하여 기준점 또

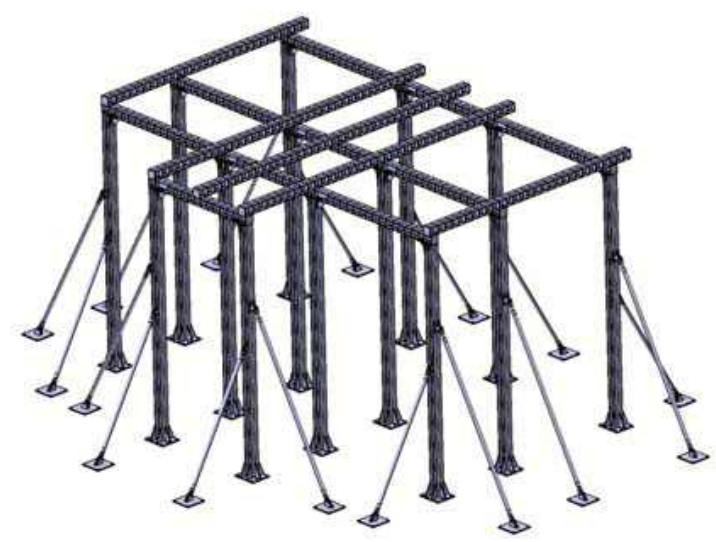

Fig. 7. Configuration of Test Frame
Table 3. Pre-loads of Springs

\begin{tabular}{|c|c|c|c|c|}
\hline \multirow{2}{*}{ 구분 } & \multicolumn{2}{|c|}{ Tension Spring } & \multicolumn{2}{c|}{ Compression Spring } \\
\cline { 2 - 5 } & $\begin{array}{c}\text { Preload, } \\
\text { N }\end{array}$ & $\begin{array}{c}\text { Installed } \\
\text { Length,cm }\end{array}$ & $\begin{array}{c}\text { Preload, } \\
\text { N }\end{array}$ & $\begin{array}{c}\text { Installed } \\
\text { Length,cm }\end{array}$ \\
\hline NLG Rx & 3,036 & 199 & 5,265 & 354 \\
\hline NLG Ry & 3,113 & 269 & 3,113 & 269 \\
\hline NLG Rz & 4,233 & 329 & 8,967 & 550 \\
\hline MLG Ry & 3,181 & 273 & 5,803 & 411 \\
\hline MLG Rz & 3,268 & 269 & 15,358 & 706 \\
\hline
\end{tabular}

는 선들이 표시되어 있고 이들은 시험체와 유압 작동기 설치에 활용된다. 시험체 자세구속장치는 시험동안 시험체가 강체운동을 구속하는 장치이 고 시험동안 시험체의 변형은 구속하지 말아야 한다. 이를 위하여 6 개의 단위 장치들이 필요하 고 현재 국내에서 가장 많이 사용하는 스프링-링 크방식 $[1,2]$ 을 본 시험에서도 사용하였다.

자세한 내용은 참고문헌 [3]에 기술되었다. 본 시험에 사용하는 6 개의 단위 장치는 각각의 스프 링-링크 조립체로 구성된다. 각 조립체는 두 개 의 스프링들을 조립하여 구성되고 각 스프링은 압축방향으로 힘을 가하면서 조립을 하게 되며, 이때 작용하는 하중의 크기를 조립체의 사전하중 (Pre-load)으로 정의한다. 각 단위장치는 인장과 압축방향의 하중방향에 대해 두 개의 Pre-load가 존재하고 이들 값들은 조립체가 부착되는 지점에 서 시험체의 허용 설계하중 크기와 관련이 있고 본 시험에 사용되는 6 개의 각 단위장치들에 대한 Pre-load들은 Table 3 과 같았다. 하중부가장치는 각 시험조건에 맞는 하중분포를 시험체에 부가할 수 있도록 하는 장치로 스트랩(또는 패드)와 휘 플트리로 구성 된다. 조종면과 플랩을 제외한 날 개와 동체는 스트랩-휘플트리로 구성하였고 단순 한 당김(pull)방식의 하중부가를 적용하였다. 조 정면과 플랩은 패드-휘플트리로 구성하여 밀고당김(push-pull)방식의 하중부가를 하였다(Fig. 8). 날개 box와 동체에 대한 자세한 장치들에 대 한 소개는 참고문헌[3]에 기술되었다. 대표적으로 첫 시험조건(U1)에 대한 하중부가장치의 정보들 은 Table 4 와 같으며, 총 23개의 유압작동기를 사용하였다. 이 Table 4의 "Test load (N)"와 "Total $(\mathrm{N})$ "은 극한하중값이고 이들은 각각 항공 기 좌표 (Fig. 2)와 로드셀 부호 규정에 따른 값

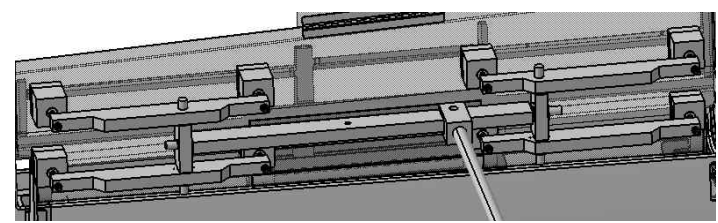

Fig. 8. Loading System for Control Surface 
Table 4. Loading System for U1 Condition

\begin{tabular}{|c|c|c|c|c|c|c|c|}
\hline & & \multirow{2}{*}{ 구루 } & \multirow{2}{*}{ Tch } & \multicolumn{2}{|c|}{ Test Loads $(\mathbb{N})$} & \multirow{2}{*}{$\begin{array}{c}\text { Total } \\
(\mathrm{N})\end{array}$} & \multirow{2}{*}{$\begin{array}{c}\text { Static Null } \\
\text { Pacing Error, } \mathrm{N}\end{array}$} \\
\hline & & & & Ultimate & Type & & \\
\hline \multirow{3}{*}{$\begin{array}{c}\text { Main Wing } \\
\text { Box }\end{array}$} & \multirow{5}{*}{ Left } & MWB_LLUP_F_IN & 7 & 4421 & 1 & 4421 & 150 \\
\hline & & MWB_L_UP_F_MID & 8 & 5197 & 1 & 5197 & 150 \\
\hline & & \begin{tabular}{|l} 
MWB_L_UP_F_OUT \\
\end{tabular} & 9 & 4992 & 1 & 4992 & 150 \\
\hline Flap & & FLAP_L_LW & 10 & 4670 & -1 & -4670 & 150 \\
\hline Aileron & & All_L_LW & 11 & 2181 & -1 & -2181 & 150 \\
\hline \multirow{3}{*}{$\begin{array}{c}\text { Main Wing } \\
\text { Box } \\
\text { Flap }\end{array}$} & \multirow{4}{*}{ Right } & MWB_R_UP_F_IN & 12 & 14847 & 1 & 14847 & 150 \\
\hline & & MWB_R_UP_F_OUT & 13 & 2654 & 1 & 2654 & 100 \\
\hline & & FLAP_R_LW & 14 & 4688 & -1 & -4688 & 150 \\
\hline Aileron & & All_R_LW & 15 & 1632 & -1 & -1632 & 150 \\
\hline \multirow{10}{*}{ Fuselage } & \multirow{6}{*}{ Vert } & F_V_FWD_EMS & 16 & -15022 & -1 & -15022 & 150 \\
\hline & & F_V_FWD_FWBKHD & 17 & -4550 & 1 & 4550 & 150 \\
\hline & & E_V_CNTR_PILOS & 18 & \begin{tabular}{|l|l|}
-1897 \\
\end{tabular} & -1 & \begin{tabular}{|l|l|}
-11897 \\
\end{tabular} & 150 \\
\hline & & F_V_PASS_FNT & 19 & -2950 & -1 & -2950 & 150 \\
\hline & & F_V_AFT_FTT & 20 & 1577 & 1 & 1577 & 100 \\
\hline & & F_V_AFT_REARBKHD & 21 & -4099 & -1 & -4099 & 150 \\
\hline & \multirow{4}{*}{ Side } & E_S_L_FWD & 22 & -2744 & 1 & 2744 & 100 \\
\hline & & F_S_R_FWD & 23 & 1713 & 1 & 1713 & 150 \\
\hline & & F_S_L_AFT & 24 & -4878 & 1 & 4878 & 100 \\
\hline & & F_S_R_AFI & 25 & 5512 & 1 & 5512 & 100 \\
\hline \multirow{2}{*}{$V / T$ Box } & & HTB_L_LW & 26 & -4134 & 1 & 4134 & 150 \\
\hline & & HTB_R_LW & 27 & -4035 & 1 & 4035 & 150 \\
\hline \multirow{2}{*}{$V / T B O X$} & Left & VTB_L & 28 & -1487 & 1 & 1487 & 100 \\
\hline & Right & VTB_R & 29 & 2087 & 1 & 2087 & 100 \\
\hline
\end{tabular}

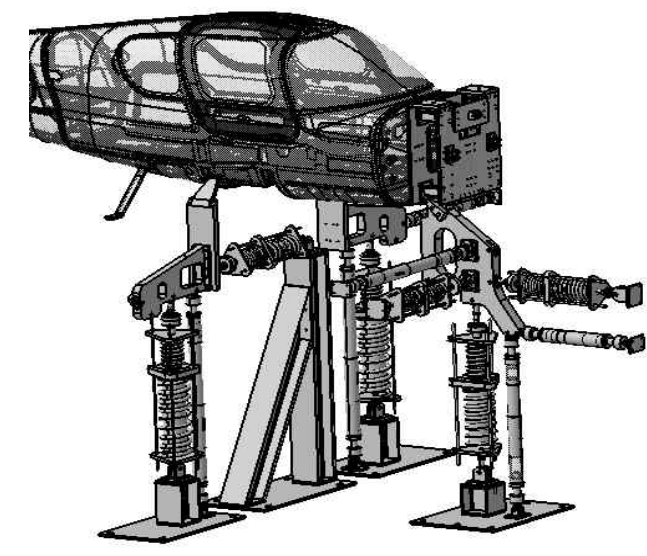

Fig. 9. Restraint and Jacking System

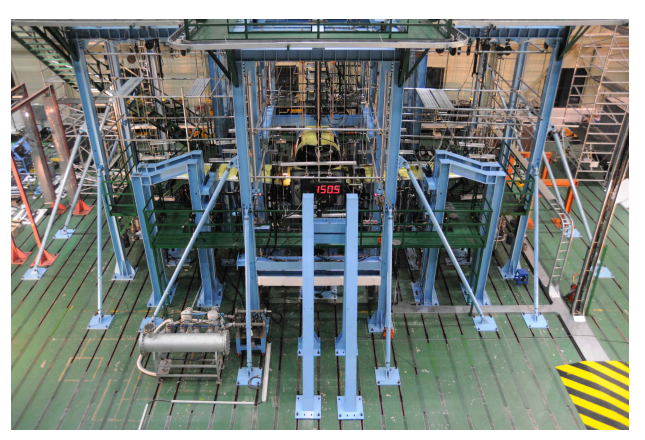

Fig. 10. Overview of U1 Test

들이다. 시험데이터들은 로드셀 부호규약에 따른 값들이 나오게 된다.

중량보상장치는 시험체의 무게와 시험치구(패 드, 스트랩, 휘플트리 등)의 무게를 윗방향으로 들어서 이 무게로 인한 시험체의 내부응력이 이 론적으로 없도록 하는 장치이다. 본 시험에서는
대부분 추와-도르레로 구성하여 사용하였고 특별 히 시험체의 변형이 별로 없는 유압작동기 및 치 구에 대한 중량보상은 번지 케이블로 제한적으로 사용한 바가 있다[3].

잭킹장치는 2.1절의 (4)항에서 설명한 바와 같 이 시험체를 정확한 위치에 설치하는 공정에서 필요하고 자세구속장치에 부착된 로드셀 교체하 고자 할 때, 자세구속장치를 시험체로부터 분리 하고 대신 잭킹장치를 사용하게 되는 장치이다. 일반적으로 유압식 장치를 이용하여 잭킹자치로 사용해 왔으나 [1, 2] KC-100 전기체 구조시험을 수행하면서 처음으로 수동으로 비교적 손쉽게 사 용할 수 있는 터언버클식 장치를 사용하였다. 자 세구속장치와 잭킹장치를 함께 나타낸 것이 Fig. 9와 같다. 잭킹장치도 시험체를 강체 이동시켜야 하므로 6 개의 단위장치로 구성되었다. 이상과 같 이 시험장치들이 설치된 대표적인 시험전경 사진 은 Fig. 10 과 같다.

\section{6 시험의 오차}

대규모 장치들이 사용되는 전기체 시험에서는 시험의 오차가 존재할 수밖에 없으며, 이들 오차 들은 허용오차를 정의하여 준비단계에서부터 적 용하여야 시험의 정확성을 유지할 수 있게 된다. 오차 요소들은 크게 장치설치오차, 장비/센서 교 정오차 및 하중제어오차의 세가지로 구분할 수 있다.

시험체와 하중부가장치의 설치는 2.1.4절에서 기술한 바와 같이 본 시험을 위하여 개발된 절차 에 따라 수행되었다. 시험체 설치의 결과는 Table 5와 같고 설치오차는 허용오차인 $\pm 2.5 \mathrm{~mm}$ 이내에서 잘 일치하였음을 보여준다.

하중부가장치 요소들인 패드와 스트랩의 설치 에 대해서도 허용오차인 각각 $2.5 \mathrm{~mm}, 5 \mathrm{~mm}$ 이내 에 잘 설치되었음을 알 수 있었고 다만, 왼쪽 플 랩에 부착된 패드 하나가 오차가 $6.0 \mathrm{~mm}$ 로 허용 오차를 벗어났으나, 이는 시험결과에 큰 영향을 주지 않을 것으로 판정하여 그대로 사용하였다.

Table 5. Result for Installation of Test Article

\begin{tabular}{|c|c|c|c|c|c|c|}
\hline ID & Station & Target & Meas. & Error & Tole. & Pass/fail \\
\hline \multirow{2}{*}{ Fuselage Reference } & FS & \begin{tabular}{|l|}
$3,785.6$ \\
\end{tabular} & $3,787.5$ & 1.9 & 2.5 & Pass \\
\hline & FS & $7,120.0$ & $7,117.5$ & 2.5 & 2.5 & Pass \\
\hline NLG_Z Fatigue Fz Hole Center (Left face) & & & & & 2.5 & Pass \\
\hline Restraint Spring_NLG_Z hole center & WL & 140.0 & 140.0 & - & 2.5 & Pass \\
\hline Restraint Spring_MLG_Z_LH hole center & WL & 258.9 & 259.0 & 0.1 & 2.5 & Pass \\
\hline Restraint Spring_MLG___RH hole center & WL & 259 & 258.5 & 0.4 & 2.5 & Pass \\
\hline Restraint Spring_NLG_X hole center & FS & 2,125 & 2124 & 1.2 & 2.5 & Pass \\
\hline Restraint_MLG_Y_RH (Front Face) & BL & 811 & 812 & 0.5 & 2.5 & Pass \\
\hline Fuselage(FWD) & BL & 0 & 0 & - & 2.5 & Pass \\
\hline Fuselage(AFT) & BL & 0 & -0.5 & 0.5 & 2.5 & Pass \\
\hline
\end{tabular}


유압작동기들의 후레임에 장착지점에 대한 측 정결과도 $2.5 \mathrm{~mm}$ 이내의 허용오차 범위내에서 설 치하였음을 확인하였다[4].

장비 교정은 하중측정 센서인 로드셀과 측정 장비를 연결한 상태에서 표준 로드셀 및 지시계 를 사용하여 목표하중을 부가한 후 시험장비에서 의 하중값이 같은 숫자가 나오도록 장비의 인자 들(게인, 인가전압, 인장압축 기울기 비 등을 조 정하여 수행한다. 측정장비와 로드셀은 선형특성 이 우수한 것들을 사용하고 있고 대표적인 교정 의 결과는 Fig. 11 과 Table 6과 같다. 실하중은 표준지시계로 나타난 값으로 기준하중이고 지시 하중은 본 시험장비에서 교정되어 나타나는 하중 이다. 본 시험에서는 여러 용량의 로드셀이 사용 되었으나 가장 많이 사용한 $25 \mathrm{KN}$ 용량 로드셀의 교정결과를 예로 보였다. 교정결과 기울기는 압 축과 인장에 대하여 각각 매우 선형성이 잘 유지 되고 있으며, 압축과 인장에 대해 이상적인 기울 기 1 과 비교하여 각각 $0.091 \%$ 와 $0.06 \%$ 정도의 기울기 오차가 존재하며, 각 측정값에서의 최대 오차정도는 압축과 인장에 대해 각각 $0.24 \%$ 와 $0.08 \%$ 정도로 매우 정확하였고 최대오차는 전체 영역에 대하여 $26 \mathrm{~N}$ 이었다.

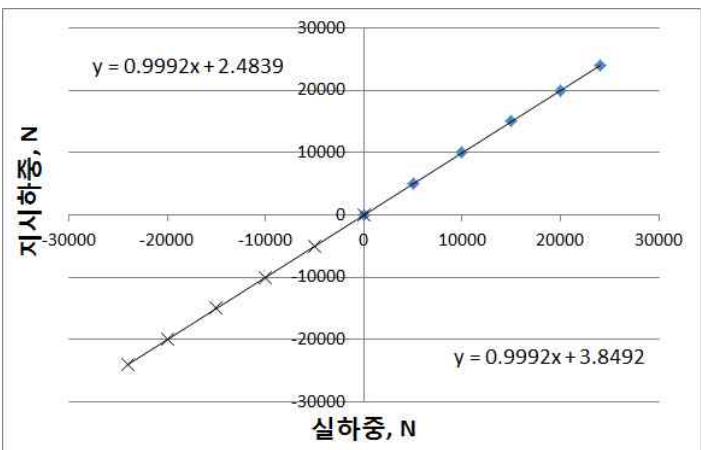

Fig. 11. Calibration Result of a Load Cell

Table 6. Calibration Result of a Load Cell

\begin{tabular}{|c|c|c|c|c|}
\hline 구분 & 실하중 & 지시하중 & 오차값 & 오차(\%) \\
\hline \multirow{4}{*}{ Comp. } & 0 & 0 & 0 & 0 \\
\cline { 2 - 5 } & 5,000 & 4,988 & -12 & -0.24 \\
\cline { 2 - 5 } & 10,000 & 9,990 & -10 & -0.10 \\
\cline { 2 - 5 } & 15,000 & 14,989 & -11 & -0.07 \\
\cline { 2 - 5 } & 20,000 & 19,988 & -12 & -0.06 \\
\cline { 2 - 5 } & 24,000 & 23,974 & -26 & -0.11 \\
\hline \multirow{4}{*}{ Tens. } & 5,000 & 5,001 & 1 & 0.02 \\
\cline { 2 - 5 } & 10,000 & 9,999 & -1 & -0.01 \\
\cline { 2 - 5 } & 15,000 & 14,995 & -5 & -0.03 \\
\cline { 2 - 5 } & 20,000 & 19,986 & -14 & -0.07 \\
\cline { 2 - 5 } & 24,000 & 23,982 & -18 & -0.08 \\
\hline \multicolumn{3}{|l|}{} & Unit : N \\
\hline
\end{tabular}

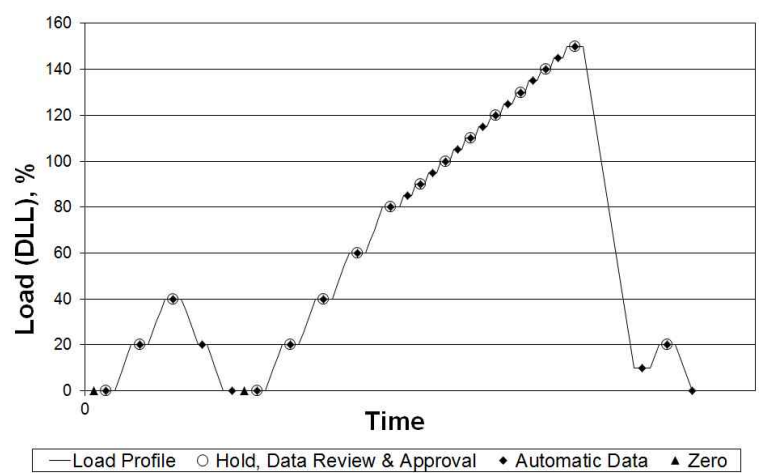

Fig. 12. Test Profile of $150 \% \mathrm{DLL}$

하중제어는 Table 2에서 보는 바와 같이 여러가 지 제어인자가 있으나 시험데이터 획득과 관련된 것은 'Static null pacing error'(SNPE)이고 이들 은 시험 데이터를 획득하는 시점에서의 각 채널의 오차허용 범위를 정의하는 것이다. 각 시험조건 별 채널별로 각각 다른 값으로 정의가 되며, U1 시험조건에 대한 SNPE값들은 Table 4와 같았다. 시험데이터의 획득시점은 사전 정의된 프로파일 에 따라 정해지고 $150 \% \mathrm{DLL}$ (design limit load) 프로파일인 경우 Fig. 12에서 보는 바와 같이 지 정된 " "표시가 있는 하중값에서만 이루어진다.

\section{7 시험 결과}

시험을 통하여 획득된 데이터들은 하중, 스트 레인, 그리고 변위들이다. 시험체의 거동 데이터 인 스트레인과 변위값은 시험체 설계자들이 분석 을 하여 시험체의 건전성을 확인하게 된다. 한편 하중데이터는 시험엔지니어가 시험의 정확성 관 점에서 분석을 하게 된다. 본 논문에서는 시험하 중 데이터만을 다루게 된다.

첫번째 시험(U1) 데이터를 이용하여 시험하중 데이터 분석결과를 소개하였다. U1 시험은 Table 4 에 있는 바와 같이 총 29 개의 하중채널로 구성 되었으며 1 6까지는 시험체 자세구속장치에 설 치된 하중 모니터용 채널이고 23 개의 제어체널로 구성되었다.

\subsection{1 제어 오차 분석}

23개의 제어채널에 대해 시험에서 획득한 제 어오차인 $\mathrm{CMF}$ (command minus feedback)값들 을 각 채널의 허용오차인 $\mathrm{SNPE}$ 의 값으로 나눈 값을 Fig. 13에서 보여주고 있다. 가장 큰 오차의 크기가 허용오차에 대하여 약 $50 \%$ 정도임을 보여 주고있다. 한편, 시험에 대한 하중제어오차의 특 성을 분석하기 위하여 참고문헌 [8]에서 제안한 방법에 따라 식(1)을 적용한 23개 제어채널의 


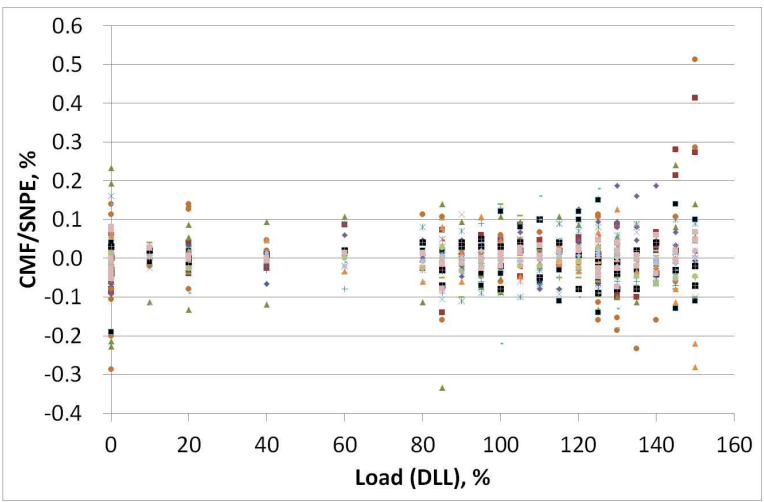

Fig. 13. Normalized CMFs by SNPE

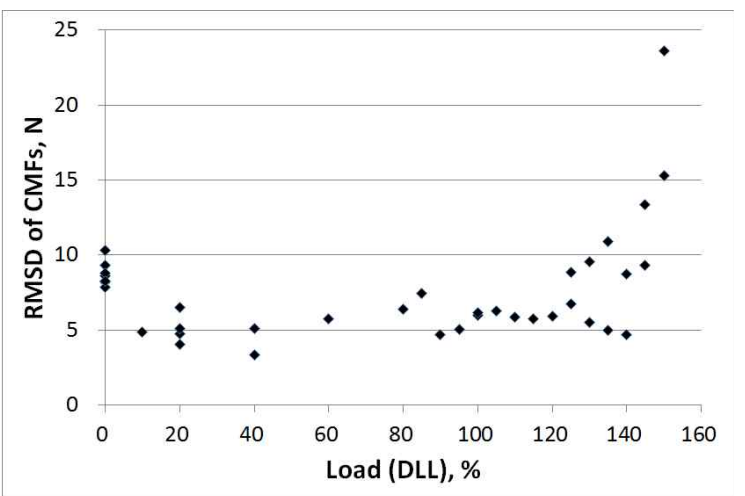

Fig. 14. RMSD of CMFs

Table 7. Result for Load Control of Tests

\begin{tabular}{|c|c|c|}
\hline 시험조건 & $\begin{array}{l}\text { Min/Max. Normalized CMF by } \\
\text { SNPE }\end{array}$ & $\begin{array}{l}\text { A v e r a g e d } \\
\text { RMSD, N }\end{array}$ \\
\hline U1 & $-0.85 / 0.51$ & 8.63 \\
\hline U2 & $-0.28 / 0.61$ & 9.25 \\
\hline U3 & $-0.83 / 0.91$ & 26.1 \\
\hline U4 & $-0.48 / 0.77$ & 19.27 \\
\hline U7 & $-0.45 / 1.01$ & 16.67 \\
\hline U8 & $-0.47 / 0.49$ & 16.26 \\
\hline U9 & $-0.44 / 0.47$ & 14.32 \\
\hline U10 & $-0.49 / 0.92$ & 22.33 \\
\hline U11 & $-0.33 / 0.43$ & 11.68 \\
\hline U12 & $-0.97 / 0.36$ & 14.88 \\
\hline U13 & $-0.54 / 0.38$ & 8.93 \\
\hline U14 & $-0.38 / 0.29$ & 7.86 \\
\hline U15 & $-1.83 / 1.37$ & 17.48 \\
\hline U22 & $-0.12 / 0.20$ & 14.03 \\
\hline
\end{tabular}

$\mathrm{CMF}$ 값들에 대한 $\mathrm{RMSD}$ (root mean square deviation) 값은 Fig. 14와 같았다. Fig. 14에서는 하중이 $150 \% \mathrm{DLL}$ 에 근접하면서 RMSD값이 크게 나타나고 있으며, 이는 시험체 안전보호를 위하 여 사용하고 있는 하중제한밸브의 작동으로 인한 영향으로 판단된다. 하중제한밸브는 최대하중을 낮추는 반면 조절된 최대하중 근처에서는 유압 작용의 불안정으로 인해 하중제어가 불안정해는 특성으로 인한 것이다.
Figure 14 의 RMSD값들에 대한 평균값으로 $\mathrm{U} 1$ 시험의 하중제어 오차 크기로 정의할 수 있 으며, $\mathrm{U} 1$ 시험조건에 대한 오차의 크기는 $8.6 \mathrm{~N}$ 이 었다. 15 가지의 나머지 전기체 시험조건들에 대 한 시험데이터를 분석한 결과 Fig. 13에서 보인 Normalized CMF값의 최대/최소값과 Fig. 14에 서 보인 RMSD 값들의 평균값을 시험조건별로 Table 7에 정리하였다. U7과 U15조건을 제외하 고는 모두 Normalized CMF값이 1.0이내임을 보 여준다. U7조건은 마지막 $150 \% \mathrm{DLL}$ 에서만 초과 한 바가 있고 $\mathrm{U} 15$ 는 너무 시험하중이 작아서 초 기 SNPE보다 큰 값으로 허용치를 풀어서 시험 한 결과이다. 이들 두가지 시험조건 외에 모든 시험은 $\mathrm{SNPE}$ 값의 $97 \%$ 이내에서 제어되었음을 보 여준다. 아울러 평균적 제어오차의 크기는 $7.8 \mathrm{~N}$ 22.3N 수준임을 보여주었다.

$$
\text { RMSD }=\sqrt{\frac{\sum_{\mathrm{i}}^{\mathrm{n}}(\mathrm{CMF})_{\mathrm{i}}^{2}}{\mathrm{n}}}
$$

\subsection{2 반력분석}

$\mathrm{U} 1$ 시험은 시험하중 2.2절에서 설명한 바와 같이 시험체의 변형이 없는 형상을 기준으로하여 자세구속장치에서 계산된 반력은 0 이 되도록 하 였다. 하지만 U1시험조건에 대한 자세구속장치에 서 측정된 반력들은 Fig. 15에서 보는 바와 같이 하중증가에 따라 반력이 증가함을 보였다. 이는 두가지 요인으로 발생될 수 있는 것으로 판단이 된다. 하나는 시험체의 형상이 변하기 때문이고 또 다른 이유는 2.5절에서 기술한 오차의 요인들 로 인하여 발생한다고 판단된다. 시험체의 형상 변화는 하중작용방향의 변화를 야기하며, 각종 오차의 용인들이 이 시스템의 힘과 모우멘트의 평형이 실제로는 유지되지 못하게 될 것이며 이 들의 불균형으로 반력이 나타나게 되는 것이다.

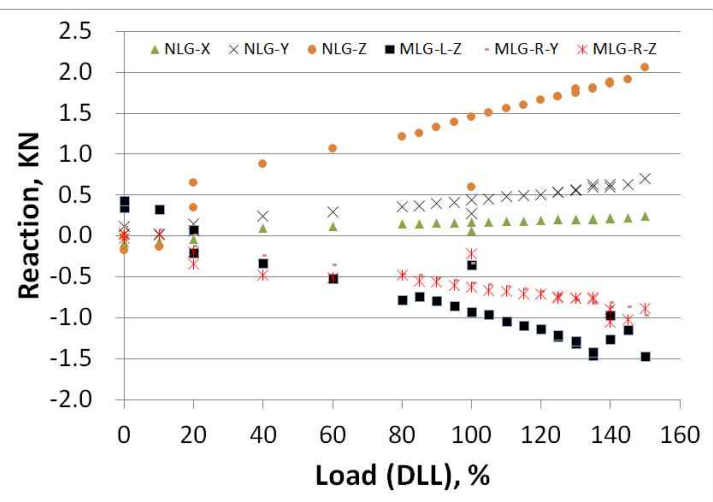

Fig. 15. Measured Reactions for U1 Test 
Fig. 15 에서 보는 바와 같이 반력이 발생하게 되 면 자세구속장치가 장착된 시험체부에 하중이 작 용되므로 이에 대한 허용하중의 크기를 정의하여 야 하고 각 시험조건별 허용하는 반력의 크기를 정의하여 시험진행 과정에서 반력의 크기를 감시 를 하여야 하고 본 시험에서도 시험체 해석담당 자들이 발행한 허용값을 넘지 않는지 주의 깊게 감시하면서 시험을 수행하였다.

\section{III. 결 론}

소형복합재료 항공기인 KC- 100 의 전기체 정적 구조시험을 수행하기 위하여 시험하중산출, 시험 장비, 시험장치의 설계, 설치를 수행하였다. 시험 의 정확성 유지를 위하여 시험체설치 및 주요시 험장치의 설치절차를 개발하여 적용하였고 설치 결과가 허용오차 이내에 잘 설치가 되었음을 확 인하였다. 시험하중 데이터 결과 분석을 통하여 시험제어가 허용된 오차인 SNPE이내에서 잘 유 지되고 있음을 알 수 있었고 전기체 시험의 제어 오차 크기는 $7.86 \mathrm{~N} \sim 22.3 \mathrm{~N}$ 범위에 있음을 알 수 있었다. 시험체 자세제어장치에서 유발되는 반력 은 시험하중이 증가하면서 증대되었고 최대 크기 는 약 $2,000 \mathrm{~N}$ 정도이고 반력의 발생 요인을 기술 하였다. 향후 연구에서는 반력의 발생요인들에 대한 정량적인 분석을 하고자 한다.

\section{References}

1) Jae-yeul Shim, Gui-Chul Hwang, Dong-Chul Chae, Kyoung-Jin Sung, Sung-Chan Kim, In-Hee Hwang, "Ultimate Load Test of Full-scale Airframe of Advanced Jet Trainer", Korean Society for Aviation and Aeronautics
Fall Conference 2004, pp.161 166.

2) Myung-Seog Yang, Jae-Kwon Jung, Shul Chang Won, Kee-Bhum Lee, "Floating Set-up Method for Full Scale Airframe Durability Test", Journal of The Korean Society for Aeronautical and Space Sciences Vol. 32 No. 2, 2004, pp. 88 94.

3) Jae-yeul Shim, Sanggeun Lee, Seok-Min Ahn, "KC-100 Full-scale Static Test System", Aerospace Engineering and Technology Vol. 1 No. 1, 2012, pp.7 18.

4) Jae-yeul Shim, Keunwan Jung, Donghwan Yoon, Seok-Min Ahn, "Installation of Test Article and Loading System for KC-100 Aircraft Full-scale Static Test", The KSAS Fall Conference 2011, pp.72 76.

5) Tae-Uk Kim, Sung Chan Kim, Jae-yeul Shim, In Hee Hwang, 2002, "Development of Test Loads and Loading System", 2002 KSME Fall Annual Meeting, pp..523 527.

6) Ik-Hyeon Choi, Seok-Min Ahn, "A Study on Calculation of Test Load of Full-Scale Airframe Structural Test of Composite Aircraft", Aerospace Engineering and Technology Vol. 10 No. 2, 2011, pp.146 153

7) Sung-Chan Kim, Sung-Jun Kim, Jae-yeul Shim, 2002, "Development of Test Equipment and Fixture for T-50 Full-Scale Airframe Static Test", The 8th Symposium on Aircraft Development Technology, 2002, pp. 360 363.

8) Jae-yeul Shim, Sanggeun Lee, Seok-Min Ahn, "Analysis of Test Load Data of KC-100 Aircraft Full-scale Static Test", The KSAS Fall Conference 2012, pp.340 343. 